\title{
STRANICKÁ HISTORIOGRAFIE NA FILOZOFICKÉ FAKULTĚ UNIVERZITY KARLOVY V LETECH 1953-1970
}

\author{
JAN CALTA
}

\section{HISTORIOGRAPHY OF THE COMMUNIST PARTY OF CZECHOSLOVAKIA AT THE FACULTY OF ARTS OF THE CHARLES UNIVERSITY IN 1953-1970}

The Department of History of the Communist Party of Czechoslovakia and History of the Workers' Movement had existed at the Faculty of Arts in 1953-1970. It was supposed to focus mainly on teaching, in particular on educating the future staff of departments of Marxism-Leninism and historians who would focus on the history of the Communist Party. The department was, however, also highly active in research and its members participated in creating new historical narratives and interpretation schemes of Communist Party historiography. This study presents an analysis of the methodological foundations and historiographic production of this Charles University department.

Keywords: Department of History of the Communist Party of Czechoslovakia and History of the Workers' Movement - party historiography - Marxism-Leninism - discourse - historical narrative

DOI: $10.14712 / 23365730.2018 .11$

Stranická historiografie se stala začátkem padesátých let nově etablovaným oborem československého dějepisectví. Měla za úkol komplexně zpracovat dějiny komunistické strany a dělnického hnutí v duchu vládnoucí marxisticko-leninské teorie. Obor byl považován za samostatnou součást historické vědy se svébytnými teoretickými a metodologickými postupy. Politická a agitační podmíněnost oboru byla v době vzniku považována za samozřejmost. Nastupující generace stranických historiků měla vytvářet nové historické narativy a výkladové vzory, které by sloužily k politické indoktrinaci společnosti, a tím napomáhaly urychlené legitimizaci zásadní socialistické přestavby sociálního a politického systému. Jednalo se o naprostý rozchod s dotud používanými metodami a výklady buržoazní historiografie. Klíčovou institucí, jejímž úkolem bylo určovat a regulovat veškeré dění ve stranické historiografii, se stal Ústav dějin KSČ, založený roku 1950 při ústředním výboru KSČ. Při nedostatku vyškolených historiků však bylo nezbytné etablovat stranické dějiny také jako učební obor v rámci československého vysokého školství. Jedním z nejpřednějších vysokoškolských pracovišt' v oboru se v roce 1953 stala na Filozoficko-historické fakultě Univerzity Karlovy zřízená katedra dějin KSČ, která navázala na činnost stejnojmenné katedry z právě zrušené Vysoké školy politických a hospodářských věd (VŠPHV). Fungovala zde, byt' od roku 1964 v reorganizované podobě a pod jiným názvem (katedra dějin dělnického hnutí), až do svého zrušení novým normalizačním vedením v roce 1970. 
Co se týče literatury a pramenů, jsme v otázce institucionálního vývoje katedry odkázáni především na archivní prameny uložené v Archivu Univerzity Karlovy, ve fondu filozofické fakulty (katedra dějin KSČ, katedra dějin dělnického hnutí, spisy děkanátu, fakultní organizace KSČ, personálie) s částečnou pomocí odborné literatury. ${ }^{1}$ Spíše doplňkovým pramenem jsou paměti, biografie a sborníky věnované jednotlivým historikům, působícím na fakultě v daném období. ${ }^{2} \mathrm{~V}$ otázce stranické historiografie jsou zásadním zdrojem informací průkopnické práce Vítězslava Sommera. ${ }^{3}$ Zmínit lze i neprŕiliš povedenou práci Josefa Hanzala. ${ }^{4}$ Nápomocny mohou být i některé práce zabývající se možnostmi interpretace marxistické historiografie či marxistického revizionismu. ${ }^{5}$ Analyzováno bylo také přibližně na čtyřicet monografií, kolektivních prací či tematických sborníků publikovaných na katedře za dobu její existence, stejně jako články publikované v předních periodicích stranické historiografie. Jedná se zejména o Př́spěvky $k$ dějinám KSČ a Československý časopis historický. Důležitým zdrojem textů se stal i hlavní teoretický časopis komunistické strany Nová mysl a v neposlední řadě i katedrové periodikum s názvem Zprávy kateder dějin KSČ a dějin SSSR a KSSS. Tento výčet je samozřejmě pouze orientační a neklade si nárok na úplnost.

Cílem předkládané studie je alespoň v základních a podstatných rysech zmapovat historiografickou produkci katedry za celou dobu její existence. Především se pokusíme najít odpověd' na několik klíčových otázek: Jaké teoreticko-metodologické východisko umožní

1 Jakub JAREŠ - Matěj SPuRnÝ - Katka VolnÁ a kol., Náměstí Krasnoarmějců 2. Učitelé a studenti Filozofické fakulty UK v období normalizace, Praha 2012; Jan HavrÁneK a kol., Dějiny Univerzity Karlovy, IV, 1918-1990, Praha 1998; Pavel URBÁšEK - Jiří PUlEC, Vysokoškolský vzdělávaci systém v letech 1945-1969, Olomouc 2012; John Connelly, Zotročená univerzita. Sovětizace vysokého školství ve východním Německu, věeských zemích a v Polsku v letech 1945-1956, Praha 2008; Josef Petráň, Filozofové dělají revoluci. Filozofická fakulta Univerzity Karlovy během komunistického experimentu (1948-1968-1989), Praha 2015.

2 František KavKa, Ohlédnutí za padesáti lety ve službě českému dějepisectví, Praha 2002; Josef PoLIŠENSKÝ, Historik v měnícím se světě, Praha 2001; Růžena Mužíková a kol., Václav Husa, AUC - Philosophica et Historica, Velké osobnosti Filozofické fakulty Univerzity Karlovy 5/1988, Praha 1989; Jiří ŠTAIF (ed.), Pocta profesoru Zdeňku Kárníkovi: sborník k jubilantovým sedmdesátinám, Praha 2003; Bohumil JiroušEK, Josef Macek. Mezi historii a politikou, Praha 2004.

3 Vítězslav Sommer, Angažované dějepisectví. Stranická historiografie mezi stalinismem a reformním komunismem (1950-1970), Praha 2011; TÝŽ, Stranické dějepisectví a československá reforma, in: Jan Mervart - Jiř́ Štěpán (edd.), České, slovenské a československé dějiny 20. století, III, Osudové osmičky v našich dějinách, Ústí nad Orlicí 2008, s. 355-361; TÝž, Tři fáze stranického dějepisectví v padesátých a šedesátých letech, in: Bohumil Jiroušek (ed.), Proměny diskursu české marxistické historiografie (Kapitoly z historiografie 20. století), České Budějovice 2008, s. 271-286; TÝž, Historiografie jako součást politiky. Zakladatelské období stranického dějepisectví v Československu (1950-1955) a jeho kořeny, in: Markéta Devátá - Doubravka Olšáková - Vítězslav Sommer - Peter Dinuš, Vědní koncepce KSČ a její institucionalizace po roce 1948, Praha 2010 , s. 97-157; TÝž, Odboj a revoluce nebo zápas o charakter národní existence? Dvě historiografické koncepce dějin protektorátu a odboje v kontextu československé reformy šedesátých let, in: Jiří Plachý - Ivo Pejčoch (edd.), Okupace, kolaborace, retribuce, Praha 2010, s. 153-165.

4 Josef Hanzal, Cesty české historiografie 1945-1989, Praha 1999.

5 Bohumil JiRouŠEK, Česká marxistická a marxisticko-leninská historiografie-možnosti a meze studia, in: Český časopis historický (dále ČC̆H) 104/4, 2006, s. 884-905; TÝž (ed.), Proměny diskursu české marxistické historiografie (Kapitoly z historiografie 20. století), České Budějovice 2008; Martin Nod, Možné přistupy ke studiu dějin české historické vědy v letech 1945-2000, Soudobé dějiny (dále SD) 8/1, 2001, s. 9-22; TÝž, Dějepisectví mezi védou a politikou: Úvahy o historiografii 19. a 20. století, Brno 2007; Peter Heumos, Geschichtswissenschaft und Politik in der Tschechoslowakei. Entwicklungstrende der zeitgeschichtlichen Forschung nach 1945, Jahrbücher für Geschichte Osteuropas 26, 1978, s. 541-600; Eva SchmidT-Hartmann, Forty Years of Historiography under Socialism in Czechoslovakia. Continuity and Change in Patterns of Thought, Bohemia 29/2, 1988, s. 300-324; Michal KоРЕČEK, Hledání ztraceného smyslu revoluce. Zrod a počátky marxistického revizionismu ve střední Evropě 1953-1960, Praha 2009. 
adekvátní interpretaci stranické historiografie? Jaký byl podíl katedrových historiků na nově se utvářejících výkladových schématech a historických narativech? Která témata stranické historiografie byla na katedře preferována, a která naopak opomíjena? Sledovala katedra progresivní výkladové vzory spojené zejména s reformním projektem československé společnosti $v$ šedesátých letech, či spíše vzory regresivní?

\section{Teoreticko-metodologický úvod}

Jsem toho názoru, že paušální odmítání stranické historiografie jako vědomé falzifikace dějin, psané pouze na politickou objednávku, není př́iliš konstruktivní a je slepou uličkou dnešního historiografického diskurzu. Naopak interpretace stranické historiografie padesátých a šedesátých let jako standardní historické vědy, která přes řadu specifik vykazovala závazná pravidla a postupy, výkladová schémata a interpretační vzorce, jež by měly být předmětem nezaujatého př́stupu, nabízí široké badatelské pole. Nosná se tak zdá být Sommerova definice historie jako konstruovaného diskurzu o minulosti. Jinými slovy každá historiografie $\mathrm{v}$ jakékoliv době vytváří $\mathrm{v}$ rámci svého diskurzu vlastní závazné př́ístupy a interpretace, které většinou nejsou a často ani nemohou být slučitelné, a jelikož neexistuje žádná jediná ideální historiografie, která by předepisovala jediný možný způsob psaní o minulosti, tak nám nezbývá než připustit pluralitu historiografí́, a tím i pluralitu vědeckých pravidel a výkladových schémat. ${ }^{6}$ Samožrejmě nelze popř́it, že psaní stranických dějin mělo sloužit konkrétním politickým cílům, avšak propojení stranickosti a vědeckého př́istupu by nemělo být vnímáno jednostranně skrze černobílou dichotomii nadřízenosti a podř́zenosti, nebot' právě stranický úhel pohledu byl považován za nezbytné východisko jakéhokoliv historického bádání a jeho vědecké objektivity. Věda a politika nebyly ve stranické historiografii v opozici, nýbrž vytvářely naopak hustou sít' vzájemně působících impulzů. Teorie marxismu-leninismu tak nebyla jen jakousi svěrací kazajkou, byt vytvářela nevyhnutelné paradigmatické východisko veškerého bádání, ale také určitým podnětem $\mathrm{v}$ oblasti metodologické, zejména $\mathrm{v}$ př́klonu $\mathrm{k}$ dějinám viděným zdola skrze dělnickou třídu, ale i např́iklad v hledání nových periodizačních mezníků českých dějin. Straničtí historici byli nepochybně nuceni respektovat závazné paradigma stranické historiografie, v rámci jehož mantinelů vytvářeli vlastní svébytné historické narativy. Nabízí se však otázka, zda spíše než o vynuceném podřízení není, alespoň v některých případech, vhodnější mluvit o samostatném a aktivním podílu nastupující generace stranických historiků na utváření nových výkladových schémat, která se stala inherentní součástí společenského a politického diskurzu a o jejichž platnosti málokdo z prŕslušníků této generace pochyboval, alespoň v počáteční stalinské fázi.

Vítězslav Sommer ve své již výše zmíněné práci aplikuje na stranickou historiografii Kuhnovu teorii, založenou na formulaci období utváření, období stability a období změny vědeckého paradigmatu. Zastávám názor, že $\mathrm{v}$ daném období $\mathrm{k}$ žádné paradigmatické změně nedošlo. Stranická historiografie měla od svého počátku jasně zformulované paradigma, nebot' nevznikala ve vakuu, ale zřetelně navazovala na závazné vzory historiografie sovětské, jejíž závěry musely být v první polovině padesátých let automaticky přebírány.

6 V. Sommer, Angažované dějepisectví, s. 51. 
Závazným východiskem všech stranických historiků tak po celé období byla teorie marxismu-leninismu, ${ }^{7}$ nezpochybnitelná vedoucí úloha strany a vnímání dějin stranickou perspektivou, socialismus jako jediné možné a finální státní a společenské uspořádání, tř́ídní antagonismus jako hybný moment dějinného vývoje či všudypř́itomná dichotomie revolučního a reformního směru $\mathrm{v}$ dělnickém hnutí. Ve své studii tak vycházím z předpokladu, že $\mathrm{k}$ ustavení paradigmatu stranických dějin došlo již v první polovině padesátých let a přes některé bouřlivé diskuse $\mathrm{v}$ druhé polovině let padesátých se jednalo pouze o dílčí proměnu některých výkladových schémat, nikoliv o ustavení paradigmatu nového. Mohu jen potvrdit názor B. Jirouška, že se v podstatě jednalo o odlišné strategie, které by měly být nahlíženy jako spory uvnitř paradigmatu, jako jeho jisté dílčí posuny, nebot' pouze historici, kteří se $\mathrm{k}$ marxismu nikdy nepřihlásili, př́padně se od něho jakýmkoliv způsobem distancovali, se sami vyřazovali $z$ dosahu dobově vládnoucího paradigmatu. ${ }^{8}$ Těmto historikům však bylo pochopitelně znemožněno své práce publikovat a dočkali se oborové ostrakizace a perzekuce ze strany státních orgánů. Také významný německý historik Martin Sabrow nahlíží socialistické dějepisectví jako dynamický systém značně proměnlivé povahy, ale přesto si v jakýkoliv okamžik uchovávající svoji nezaměnitelnou identitu. ${ }^{9}$ Kritický potenciál, objevivší se po XX. sjezdu KSSS, měl jednoznačně stanovené limity, nebot' komunistická strana pochopitelně zůstala pro stranické historiky úhelným kamenem jimi vytvářených narativi̊.

Je třeba upozornit, že se zabývám pouze historiografickou produkcí na katedře dějin KSČ a dějin dělnického hnutí na Filozofické fakultě Univerzity Karlovy. Přesto jsem toho názoru, že se jedná o dostatečně reprezentativní vzorek pro pokus o jisté generalizace $\mathrm{v}$ rámci celé stranické historiografie, nebot' katedra, tak jako jiné instituce zabývající se stranickými dějinami, musela respektovat a jistým způsobem i kopírovat vývoj v oboru a plnit výzkumné plány, určované především centrální institucí stranické historiografie, kterou byl Ústav dějin KSČ. Nezbytným předpokladem pro analýzu katedrové produkce navíc bylo obeznámení se s řadou obecně teoretických a metodologických článků i nekatedrových historiků, které postihují základní dění a proměny v celé stranické historiografii.

Jakým způsobem tedy analyzovat dynamiku proměny některých historických narativů a interpretačních postupů, která se $\mathrm{v}$ námi sledovaném období bezpochyby udála? Klíčovým pojmem je diskurz, kterým můžeme nahradit méně vhodný termín paradigma. $\mathrm{V}$ př́ipadě stranické historiografie se tak jedná o normativně orientovaný vědecký diskurz, nebot' jednotlivci i sociální skupiny jednají jako vědomím obdařené subjekty, projektují svoji činnost a stavějí si společenské cíle v kontextu hodnot. Normativní pohled rekonstruuje nejen chronologii událostí, nýbrž hledá také jejich smysl, intence se tak stává klíčovým pojmem k pochopení smyslu dějin. ${ }^{10}$ Diskurz chápu především jako kategorii podřízenou paradigmatu, dobový diskurz může být veden pouze na základě znalosti a uznání platnosti dobového paradigmatu, které je nadřazeno. Ve stranické historiografii padesátých a šedesátých let se tak dá hovořit o stalinském, poststalinském nebo reformním diskurzu, které spolu dlouhé roky koexistovaly, soupeřily a ve vzájemné interakci vytvářely nové historické narativy,

\footnotetext{
7 Ponechme stranou otázku, jakou skutečnou znalostí marxistické teorie většina stranických historiků disponovala.

8 B. JIROUŠEK, Česká marxistická a marxisticko-leninská historiografie, s. 903.

9 Martin SABRow, Historiografie NDR jako badatelský problém, SD 7/1-2, 2000, s. 9-36, zde s. 28.

10 Světla ČmejRková - Jana Hoffmannová (edd.), Jazyk, média, politika, Praha 2003, s. 19.
} 
byt' s postupujícím časem byl stalinský diskurz marginalizován ve prospěch diskurzu poststalinského. V otázce zvolené periodizace je rok 1956 (XX. sjezd KSSS) ve stranické historiografii poměrně jednoznačným mezníkem. $\mathrm{V}$ př́ípadě katedry dějin KSČ se tak jedná o velmi krátké období stalinské fáze, nebot' katedra byla založena v roce 1953 . V této fázi se katedra věnovala zejména pedagogickým povinnostem, a to na úkor badatelských výsledků, kterými ostatně byly publikace agitačního charakteru. Otázkou zůstává, jakou periodizaci zvolit pro období let 1956-1970. Jednalo se o období značného názorového i metodologického vření, a tím také utváření nového diskurzu stranických dějin, který se po mém soudu kontinuálně proměňoval až do roku 1970. Přesto může být orientačním bodem rok 1963, kdy začalo docházet k radikálnější proměně základních narativů, navíc s přihlédnutím $\mathrm{k}$ faktu, že v tomto období se začala připravovat reorganizace katedry, v jejímž důsledku došlo k rozšíření badatelského záběru katedry i na dějiny mezinárodního dělnického hnutí.

\section{Období stalinského diskurzu (1953-1956)}

Katedra dějin KSČ (dějin dělnického hnutí) vznikla jako součást Vysoké školy politických a hospodářských věd (VŠPHV), založené v roce $1949 .{ }^{11}$ Hlavním cílem této instituce bylo vzdělávání nových administrativních kádrů v duchu marxismu-leninismu, stejně jako produkce základních vysokoškolských učebních textů (teze přednášek, skripta, metodické pomůcky). Avšak existence VŠPHV neměla př́liš dlouhého trvání, nebot' vládním usnesením č. 40/1952 Sb. z 19. srpna 1952 o dalších změnách v organizaci vysokých škol došlo k 1. záŕí 1953 k její reorganizaci a poté k postupnému zrušení. Fakulta společenských věd byla tímto usnesením inkorporována do Filozoficko-historické fakulty Univerzity Karlovy, kam přešla také většina jejích pedagogů a studentů.

Oficiálně začala katedra dějin KSČ na Filozoficko-historické fakultě Univerzity Karlovy fungovat od 1. záŕí 1953. Ze starších pracovníků, aktivně činných již na VŠPHV, přešli $\mathrm{v}$ rámci reorganizace na novou fakultu Jaroslav Kladiva (vedoucí katedry), Lubomír Vebr, Vladimír Dubský, Vladimír Kašík, Oldřich Prudel, Vlastimila Vesecká (později provdaná Křepeláková) a Lubomír Vejnar. Jako nově příchozí posily byli na katedru zařazeni Karel Bartošek, Karel Pichlík, Zbyněk Hejda a Drahomír Bárta. Hlavní pracovní náplní katedry měla být výchova vysokoškolských pedagogů, od nichž se očekávalo, že se pedagogicky uplatní zejména na katedrách základů marxismu-leninismu. Stav katedry byl počátkem zimního semestru 1954/1955 rozšířen o další čtyři členy (Zdeněk Kárník, Květoslava Kořalková, Jan Měchýř a Jaroslav Šauer). Dlouholetým kolektivním úkolem všech členů katedry se od roku 1954/1955 stalo vypracování vysokoškolské učebnice s názvem Úvod do

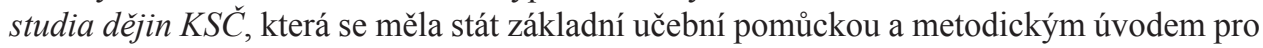
začínající stranické historiky na všech vysokých školách. Jednalo se o zpracování problémů

11 Markéta DeváTÁ, Vysoká škola politických a hospodářských věd, in: Antonín Kostlán - Markéta Devátá (edd.), Semináře a studie k dějinám vědy. Práce z dějin vědy 21, Praha 2009, s. 421-456; Markéta DevÁTÁ - Doubravka OıšÁková, Vysoká škola politických a hospodárských véd (1949-1953). Počátky marxistického vysokého školství, in: Markéta Devátá - Doubravka Olšáková - Vítězslav Sommer - Peter Dinuš, Vědní koncepce KSČ a její institucionalizace po roce 1948, Praha 2010, s. 159-212; František KaVKa, Historie na Vysoké škole politických a hospodářských věd, in: Zdeněk Beneš - Bohumil Jiroušek - Antonín Kostlán (edd.), František Graus - člověk a historik, Práce z dějin vědy 8, Praha 2004, s. 33-38. 
periodizace a zásad metodologie dějin KSČ, bibliografické soupisy k jednotlivým etapám vývoje a zhodnocení dosavadní literatury a pramenů. Tato učebnice však byla povýtce dokončena a vydána až v roce $1962 .{ }^{12}$ Dủležité změny se udály v tomto období také v pedagogické práci katedry, nebot' na základě rozhodnutí ministerstva školství a kultury byly od školního roku 1956/1957 sloučeny studijní obory dějin KSČ a dějin KSSS do oboru jednoho.

Již v tomto období bylo zformulováno výchozí paradigma stranické historiografie, které přes určité proměny některých historických narativů vykazovalo platnost po celé námi sledované období. ${ }^{13}$ Kanonickým vzorem domácí stranické historiografie se stal tzv. Stručný výklad dějin $V K S(b) .{ }^{14}$ Nově vytvářené narativy měly sloužit $\mathrm{k}$ legitimizaci socialistického režimu a vytvořit jistý zakladatelský mýtus, v němž strana hrála ústřední roli. Takto konstruované historické práce se vyznačovaly jednoduchou tezovitostí, až didaktičností, které měly oslovit širší veřejnost, a také značně omezeným využitím archivních pramenů, jež pouze naplňovaly předem stanovené teze. $V$ př́ípadě rozporu mezi stranickým viděním dějin a mluvou archivních pramenů nebylo př́iliš složité zavrhnout výsledky archivního bádání jako buržoazně objektivistické a faktografické. ${ }^{15}$ Hlubší teoretické uchopení problematiky bylo jednoduše a víceméně povinně nahrazováno citací klasiků marxismu-leninismu.

Publikační aktivita členů katedry byla $\mathrm{v}$ tomto zakladatelském období omezená (sedm monografií a jen několik článků a statí nevalné úrovně). Čtyři z těchto monografií jsou spojeny se jménem aktivního Karla Pichlíka; dvě napsal sám a ve dvou př́padech se spoluautorem Karlem Bartoškem. Lze konstatovat, že právě autorské duo Bartošek-Pichlík nejvíce splňovalo stranický požadavek na odhalování vnějších i vnitřních nepřátel socialistického zřízení. Publikace o působení americké armády v západních Čechách se zaměřila především na nepř́itele vnějšího. ${ }^{16}$ Americká armáda tak byla v očích socialistické společnosti demaskována nikoliv jako spojenec a osvoboditel, nýbrž jako okupační mocnost a hlavní nacistický spojenec, který byl již v předválečném období klíčovým zákulisním hybatelem mnichovské dohody. Popis hospodářské devastace a exploatace obsazeného území je spojen s denunciací pokleslého západního stylu života a konzumní kultury (mravní úpadek, gangsterismus, pornografie atd.). Kniha reagovala také na právě probíhající politický proces s protistátním spikleneckým centrem Rudolfa Slánského. Odhalení provázanosti domácích nepřátel a špiónů mělo $\mathrm{v}$ očích socialistické společnosti legitimovat drakoničnost vynesených rozsudků. Lze konstatovat, že z propagandistického hlediska se jednalo o nejradikálnější text, který na katedře vznikl za celou dobu její existence.

Druhým, ne-li hlavním strašákem byl pro komunistickou stranu nepř́tel vnitřní, mající podobu zrádné ideologie „sociáldemokratismu“ či „reformismu“, často označované také jako pravicový oportunismus. Zde se formuje jeden z paradigmatických prvků stranické historiografie padesátých a šedesátých let, který přes jisté proměny v rámci historického diskurzu nikdy nezmizel z hledáčku stranických historiků. Postava reformistického zrádce,

12 Jaroslav KLadiva (ed.), Úvod do studia dějin KSČ, Praha 1962.

13 Jsem toho názoru, že dokonce ani po nástupu normalizace se výchozí paradigma stranické historiografie nezměnilo. Ovšem takové tvrzení by si vyžádalo potvrdit či vyvrátit dlouhodobým studiem, které nevyhnutelně nemůže být předmětem této práce.

14 Dějiny V̌sesvazové komunistické strany (bolševiků). Stručný výklad, Praha 1953.

15 M. SABrow, Historiografie NDR, s. 28.

16 Karel BARTOŠEK - Karel Pichlí, Američané v západních Čechách v roce 1945, Praha 1953. 
který svou zdánlivě revoluční rétorikou a reformním, ba kompromisním př́stupem k buržoazní demokracii páchá zradu na dělnickém hnutí, patří ke klasickým topoi stranické historiografie námi sledovaného období. Této v podstatě zakázky stranického vedení se opět ujal osvědčený tandem Bartošek-Pichlík, jenž zvládl zpracovat dlouholetou činnost sociální demokracie na Plzeňsku v rozmezí několika měsíců první poloviny roku $1954 .{ }^{17}$ Apriorní teze o zrádném „sociáldemokratismu“ byla v publikaci doložena měrou vrchovatou. Čtenář si tak mohl plně uvědomit nekalé záměry reformistů, kteří odvrhli revoluční třídní boj a snahu o nastolení diktatury proletariátu na úkor každodenního parlamentního politikaření. Hlavní narativní linií je proměna reformistické ideologie v ideologii „sociálfašismu“, která byla hlavní př́činou Mnichova a kapitulace před nacismem, čemuž mohlo být s pomocí Sovětského svazu zabráněno. Práce opět vrcholí obhajobou politických procesů z počátku padesátých let, které byly nezbytnou očistou od sociálnědemokratických reziduí, bránících plnému vítězství ideologie ortodoxního marxismu-leninismu.

Druhým zrádným vnitřním nepř́itelem byla činnost T. G. Masaryka, souhrnně označovaná jako ideologie masarykismu, která byla schopna do své teorie inkorporovat i další zrádné ideologie jako např. kosmopolitismus či buržoazní nacionalismus, a byla tak genetickým souputníkem reformního socialismu. ${ }^{18}$ Tuto problematiku reflektovala zejména práce Drahomíra Bárty, pojednávající o generální stávce v roce $1920 .{ }^{19}$ Masaryk je zde odhalen jako hlavní buržoazní ideolog, jenž svými demagogickými teoriemi usiluje o záchranu buržoazního řádu. Zvláštní nebezpečí znamenala především Masarykova práce Sociální otázka, která byla sofistikovanou kritikou marxistického myšlení. Masaryk musel být jako hlasatel pomalé, nenásilné a evoluční cesty $\mathrm{k}$ socialismu, usilující odvrátit pracující lid od revoluční cesty, jakou nastoupil sovětský lid, jednoznačně zavržen. Druhou linií Bártovy práce je analýza chyb, jichž se dopustila levice $\mathrm{v}$ sociální demokracii. S její pomocí se snažil dokázat nezbytnost existence revoluční strany, která by postavila tř́dní boj na správných ideologických základech. Právě chybějící znalost teorie marxismu-leninismu, revoluční teorie, historických zákonů společenského vývoje i absence obeznámenosti s taktikou a strategií proletářského boje vedla levici v rozhodující chvíli k zaujetí chybného postoje. Opět je tu motiv zákonitého vzniku revoluční komunistické strany, která se stane avantgardou proletariátu. Zajímavým a poměrně symptomatickým faktem zůstává naprosté opomenutí hospodářských aspektů, které by podle klasického marxistického učení měly tvořit základnu pro politicko-ideologickou nadstavbu.

Jistým posunem je v tomto ohledu práce Lubomíra Vebra o mostecké stávce horníků v roce $1932 .{ }^{20}$ Celá první třetina knihy je věnována hospodářským a sociálním statistikám na počátku velké hospodářské krize. Přestože se jedná o velmi hutný a suchý faktografický výčet bez hlubší analýzy statistických ukazatelů, lze tuto práci označit, s vědomím všech limitů dané doby, za nejzdařilejší počin na katedře v jejím zakladatelském období. Pozitivem je i snaha zasadit mosteckou stávku do mezinárodního kontextu, nebot' autor nachází

17 Tiтiž, Z dějin dělnického hnutí na Plzeňsku. O úloze pravicových sociálních demokratů, Praha 1954.

18 Je třeba ovšem upozornit, že osobnost T. G. Masaryka se těšila v diskurzu stranické historiografie poměrně vrtkavému osudu. Ještě na přelomu čtyřicátých a padesátých let byl Masaryk s poukazem na některá problematická místa jeho politické kariéry celkem bezproblémovou součástí standardního narativu československých dějin, avšak postupně v první polovině padesátých let došlo k radikálnímu obratu, ve kterém byl Masaryk odhalen jako hlavní buržoazní ideolog.

19 Drahomír BÁrTa, Prosincová generálni stávka roku 1920, Praha 1953.

20 Lubomír VeBr, Mostecká stávka 1932, Praha 1955. 
jistou genetickou linii se stávkami krakovských a dombrowských horníků v Polsku. Určitou slabinou, zejména z hlediska stranické propagandy, se může zdát absence jakékoliv ucelenější teorie a generalizace závěrů plynoucích z mostecké stávky pro další vývoj strany a revolučního hnutí.

V zakladatelském období stranické historiografie bylo na katedře dále publikováno jen pár nepř́liš významných monografií menšího rozsahu. Jedná se zejména o práce Karla Pichlíka, zabývající se problematikou revolučního hnutí v rakousko-uherské armádě v průběhu první světové války. ${ }^{21}$ Jde o kratší brožury propagandistického ražení, vyznačující se absencí jakéhokoliv archivního výzkumu. Podobné rysy vykazuje i apologetická biografie stranického odborového předáka a stávkového organizátora Rudolfa Terera z pera Lubomíra Vejnara. ${ }^{22}$ Kupodivu v prvních letech činnosti katedry prakticky nikdo z členů nepublikoval žádné články v některém z významnějších periodik. Výjimku tvoří pouze stati či de facto celkem obsáhlé apologetické recenze Jaroslava Kladivy na V. a VI. svazek spisů Klementa Gottwalda v Československém časopise historickém. ${ }^{23}$

\section{Období poststalinského diskurzu (1956-1963)}

XX. sjezd KSSS v Moskvě v únoru 1956 znamenal společenský otřes. Po určitém uvolnění nastal v roce 1958 opět proces utužování společenských a politických poměrů. Důsledkem tohoto dění se stala prověrka třídní a politické spolehlivosti, která byla zahájena na počátku roku 1958 z rozhodnutí politického byra ÚV KSČ. Na katedře dějin KSČ došlo na přelomu roku 1957/1958 k odchodu pěti pracovníků. Situace kolem této události není zcela přehledná. Nepochybným faktem zůstává, že z katedry dějin KSČ bylo tehdy vyloučeno pět kmenových členů (Karel Bartošek, Zbyněk Hejda, Květoslava Kořalková, Karel Pichlík a Jaroslav Šauer). V krátkosti lze jen konstatovat, že rehabilitační komise v listopadu 1968 shledala názory vyloučených zcela běžnými a politicky nezávadnými a navrhla zrušení uvedených stranických trestů a plnou morální a politickou rehabilitaci jmenovaných.

V oblasti vysokoškolské výuky znamenala reflexe výsledků XX. sjezdu KSSS položení silnějšího důrazu na výuku dějin mezinárodního dělnického hnutí a jeho kontextu $\mathrm{s}$ vývojem dělnického hnutí v Československu. Neexistence oborového pracovišš specializujícího se na tuto problematiku vedla ke stále hlubší spolupráci s katedrou dějin SSSR a KSSS. Již na konci roku 1957 byla dohodnuta týmová spolupráce na nové vysokoškolské učebnici, dokončené však až roku 1965, která se stala první syntézou tohoto zaměření. ${ }^{24}$ Důsledkem ovšem bylo čím dál větší pracovní vytížení a stále častěji se ozývaly stížnosti na nadměrné pedagogické úvazky. Nezapomínejme, že pět vyloučených členů nebylo nikým nahrazeno. Teprve na začátku školního roku 1961/1962 byli nově prijiati asistenti Vlastimila Křepeláková a Ladislav Niklíček a vědecký aspirant Josef Michňák, který ovšem

21 Karel Pichlí, Bojovali proti válce. Revolučni boj českých vojáků a námořniků v rakousko-uherské armádě za imperialistické světové války 1914-1918, Praha 1953; TY̌ž, Vzpoura 71. pluku v červnu 1918, Praha 1956.

22 Lubomír Vejnar, Rudolf Terer: bojovnik proti fašismu, Praha 1955.

23 Jaroslav Kladiva, K V. svazku Spisů soudruha Klementa Gottwalda, Československý časopis historický (dále ČsČH) 1/1, 1953, s. 61-73; тÝž, K VI. svazku Spisů soudruha Klementa Gottwalda, ČsČH 1/3, 1953, s. 323-340.

24 Vladimír KAŠíK - Vladimír Suchopár (red.), Dějiny mezinárodního dělnického hnutí, Praha 1966. 
hned následujícího roku přestoupil na katedru vědeckého komunismu. Hlavní publikační platformou se od roku 1958 pro členy katedry stalo vlastní periodikum s názvem Zprávy kateder dějin KSČ a dějin SSSR a KSSS, určené k publikování badatelských závěrů, dílčích studií a informací o činnosti obou kateder. ${ }^{25}$ Odbornými redaktory byli jmenováni Lubomír Vebr a František Hrbata. Další novou publikační platformou se stal od roku 1960 vydávaný univerzitní sborník Acta Universitatis Carolinae (AUC), řada Philosophica et Historica. Hned v prvních dvou letech od vzniku sborníku byla katedře dějin KSČ přidělena dvě čísla. První číslo sborníku AUC-PhH v roce 1960 neslo název K problematice dějin ideového vývoje KSČ. Na něj katedra navázala v roce 1961 zvláštním vydáním sborníku AUC-PhH, věnovaného 40 . výročí založení Komunistické strany a nazvaného $O$ revoluční jednotu československého dělnického hnutí, které bylo posléze oceněno cenou rektora Univerzity Karlovy.

Důsledky XX. sjezdu KSSS se pochopitelně odrazily i ve stranické historiografii. Byly odsouzeny dogmatické výstřelky předchozího období, jež se přičítaly neblahému vlivu kultu osobnosti. Charakteristickým rysem řady debat se stalo volání po zvědečtění stranické historiografie, jež mělo být provedeno zejména návratem ad fontes. Mělo být opuštěno neustálé citování klasiků marxismu-leninismu, především Stalina a Gottwalda, které již dále nemohlo být považováno za dostatečně vědecký přistup k psaní stranických dějin. ${ }^{26} \mathrm{Jsem}$ toho názoru, že již v této fázi stranické historiografie můžeme mluvit o jakémsi protorevizionistickém období. Také pro katedru dějin KSČ se jednalo o důležité formativní období, nebot' většina zde působících historiků patřila k př́slušníkům nejmladší generace stranické inteligence s datem narození okolo roku 1930, kteří právě v tomto období začali odborně dozrávat a publikovat své první významnější práce, at již v podobě řady článků a statí nebo počátkem šedesátých let i prvních vědeckých monografií.

Jasné novum oproti předchozímu období představovala řada teoretických a metodologických článků, které výraznou měrou přispěly k zformování nového poststalinského diskurzu stranické historiografie (Josef Macek, Koloman Gajan, Zdeněk Šolle, Pavel Reiman, Jan Pachta). ${ }^{27}$ Kritika byla zaměřena především proti projevům kultu osobnosti v historické vědě, vyznačující se $\mathrm{v}$ daném období absolutní podřízeností politické praxi stranických orgánů a služebností v agitační a propagandistické činnosti, což bylo dáno především nekritickým a otrockým přebíráním všech výsledků sovětské historické vědy. Jen povrchní znalost marxistické teorie neumožnila invenční aplikaci historického a dialektického materialismu. Někteří autoři se také distancovali od striktně černobílé dichotomie, která byla uplatňována při dělení historických aktérů na reakční a pokrokové. „Osobnost, která hrála významnou pokrokovou úlohu, nesměla ve svém vývoji udělat chybu, a proto se nutně vyskytnuvši chyby zakrývaly, přecházely [...]. Na druhé straně osobnost, která se nakonec nějakým zpưsobem zkompromitovala nebo od strany odpadla, nesměla mít, počínajíc svým zrozením, v životě žádný kladný rys, žádnou zásluhu, třebaže skutečný vývoj nebyl

25 Jejich vydávání bylo roku 1961 ukončeno.

26 V. SOMmer, Angažované dějepisectví, s. 155.

27 Koloman GAJAN - Josef MACEK - Zdeněk ŠOLLE, K některým problémům naši historické vědy, Nová mysl (dále NM) 10/6, 1956, s. 636-640; Jan PACHTA, Dỉsledněji uplatňovat leninskou zásadu stranickosti v naší historické vědě, Příspěvky k dějinám KSČ (dále PD KSČ) 1, 1957, s. 5-14; Pavel ReImAn, Za di̊sledné uplatněni historického materialismu v dějinách Komunistické strany Československa, NM 11/3, 1957, s. 233-247; Zdeněk BRADÁČ, Poznámky k některým obecným problémům studia dějin KSČ ve dvacátých letech (Na okraj diskusního článku Vladimíra Dubského), ČsČH 6/3, 1958, s. 325-334. 
tak jednoduchý،“28 Objevily se také útoky na samu podstatu stranické historiografie jako samostatného oboru. Vedl je především Historický ústav ČSAV, a to argumentací, že stranické dějiny nejsou žádnou samostatnou vědní disciplínou podléhající vlastní historické zákonitosti, a proto nedisponují ani zvláštními metodologickými postupy, a tak by měly být podřízeny výzkumu národních dějin právě pod kuratelou Historického ústavu AV ČR. Je ovšem třeba zdůraznit, že i v tomto období měla kritika své pochopitelné limity, a tak se na druhé straně ozýval i důraz na nezbytnost boje proti opačné tendenci v historické vědě, tedy proti nebezpečí revizionismu (Bradáč, Pachta). Zvláště doyen marxistické historiografie Jan Pachta vyjadřoval obavu, aby revizionistické tendence, vyznačující se radikální kritikou kultu osobnosti, nepřerostly až v ospravedlňování buržoazní historiografie, a to zejména metod objektivismu a pozitivismu. Tyto nebezpečné tendence měly být eliminovány především striktním dodržováním stranické perspektivy a tvůrčím použitím metod marxismu-leninismu. ${ }^{29}$

Do těchto debat se aktivně zapojili i historici z katedry dějin KSČ. Př́spěvek Vladimíra Dubského ${ }^{30} \mathrm{v}$ podstatě opakoval argumenty zaměřené proti kultu osobnosti a v souladu s článkem Josefa Macka a spol. odmítal černobílé hodnocení historických osobností. Proto se zde zaměříme spíše na př́íspěvky Jaroslava Kladivy a Vladimíra Kašíka. ${ }^{31}$ Kladiva ve svém př́spěvku oponuje zejména útoku na samostatnost oboru, což je z jeho pozice vedoucího katedry dějin KSČ naprosto logické. Dějiny vnímané stranickou perspektivou chápe jako základní rys historikovy metody, nebot’ použití stranického úhlu pohledu mu umožňuje odhalovat podstatu zkoumaných jevů a věrnou reprodukci objektivních historických procesů. Pokud stranický historik aplikuje správně metodu dialektického a historického materialismu, pokud důsledně vychází z pozice dělnické třídy, která je vždy ve shodě s objektivní pravdou, tak se nemůže mýlit. Vztah mezi dějinami stranickými a obecnými shledává dialektickým, nebot' strana je podle jeho názoru zákonitým produktem konkrétního stádia obecného historického vývoje a naopak má sama aktivní vliv na utváření historického dění. Na dialektický vztah $\mathrm{v}$ dějinách naráží ve svém př́spěvku také Vladimír Kašík. ${ }^{32}$ Autor si klade otázku, v čem spočívá význam biografie pro celou historiografii. Je toho názoru, že biografie musí odpovídat na dvě klíčové otázky - na otázku po důležitých životopisných datech osobnosti, stejně jako na otázku po prríčinách historického významu osobnosti a dimenze jejího zásahu do společenského vývoje. Při sbírání dat ze života osobnosti je důležité nepodceňovat a nepřehližžet také údaje, které se týkají jejího vnitřního života, zejména v raném období vývoje, kdy se významná historická osobnost formuje ve svých názorech. Je tak povinností každého historika usilovat o co nejvěrnější rekonstrukci psychologického profilu osobnosti. Vztah mezi osobností a společností nahlíží Kašík jako dialektický, nebot' v konkrétním vývoji osobnosti se vždy projevují obecné zákonitosti

28 K. GAJAN - J. MACEK - Z. Šolle, K některým problémům naši historické vědy, s. 638.

29 V zásadě se jednalo jen o velmi vágní stanovisko, nebot' pod pojmem tvưrčí užití metod marxismu-leninismu si mohl každý představovat něco jiného.

30 Vladimír DuBsкÝ, K otázce vědeckého zpracováni vývoje KSČ v letech 1921-1925, ČsČH 5/5, 1957, s. 549-555.

31 Jaroslav KLADIVA, K metodologickým otázkám dějin KSČ, Čs ̌̆H 6/3, 1958, s. 334-344; TÝŽ, K problematice práce historiků v nejnovějšich dějinách, Zprávy kateder dějin KSČ a dějin SSSR a KSSS (dále ZK) 2/1, 1959, s. 77-91; Vladimír KAšík, Několik poznámek k metodologickým problémům v historiografii (Otázky metodologie v biografiich), С̌s $\breve{\mathrm{CH}} 6 / 4,1958$, s. 507-520.

32 V. KAší, Několik poznámek k metodologickým problémům, s. 507-520. 
vývoje společnosti, a naopak vědomé úsilí významných historických osobností se vždy ve zralém období vývoje kryje se zákonitou tendencí společenského vývoje. Dle Kašíkova soudu je možné v některých prípadech, i navzdory všeobecným dějinným zákonitostem, prosadit $\mathrm{v}$ určitém okamžiku vůli a záměry jednotlivce.

Na první pohled je poněkud zarážejícím zjištěním fakt, že v letech 1957-1960 nebyla na katedře publikována žádná monografie a první rozsáhlejší texty se objevily až v roce $1961 .{ }^{33}$ Přesto lze konstatovat, že produkce katedry byla oproti předchozímu období plodnější, nebot' došlo k publikaci řady článků a statí. Především je třeba se zmínit o kolektivní práci s názvem Úvod do studia dějin KSČ. ${ }^{34}$ Byla koncipována jako vysokoškolské skriptum, a jak název napovídá, jako prolegomena do oboru stranických dějin pro začínající historiky. Výsledek nebyl nijak oslňující, nebot' po krátkém úvodu, zabývajícím se základní terminologií, následuje v podstatě řečeno telefonní seznam stranické literatury a periodik, tištěných pramenů, stranických pracovišst', knihoven, archivů a muzeí. Do očí bijící pak je především absence analýzy marxismu a jeho myšlenkových konceptů. Navzdory těmto faktům se zdá, že přijetí učebnice bylo celkem pozitivní, nebot', alespoň v základní rovině naplnila jistá deziderata na poli výuky stranických dějin na vysokých školách.

Hlavní těžiště katedrové produkce se však soustředilo především na dějiny strany a dělnického hnutí v meziválečném období, zejména v počáteční fázi let 1917-1921. ${ }^{35}$ Klíčovým mezníkem této periody je Velká říjnová socialistická revoluce a nastolení diktatury proletariátu v Rusku. Opět byla tematizována klasická problematika reformismu v řadách sociální demokracie, jenž společně s austromarxismem, odmítajícím internacionální jednotu

33 Jak si tento fakt vysvětlit? Zaprvé se jedná o generační problém. Většina historiků působících na katedře dějin KSČ se řadila k př́íslušníkům nejmladší badatelské generace, kteří právě v průběhu druhé poloviny padesátých let psali své práce doktorské, jejichž výsledky byly publikovány až začátkem let šedesátých. K tomu je třeba přičíst i pracovní vytíženost jak badatelského rázu, podílem na dvou kolektivních syntézách, tak rázu pedagogického. V průběhu celé druhé poloviny padesátých let byli prakticky všichni členové katedry součástí širokého kolektivu stranických historiků, který byl pod kuratelou Ústavu dějin KSČ pověřen vypracováním učebnice dějin KSČ, jejíž vznik nesnesl žádného odkladu. To se stalo prvořadou záležitostí sledovanou z nejvyšších pater stranické nomenklatury. Navíc sama katedra byla pověřena v rámci rezortního úkolu ministerstva školství vypracováním metodické př́ručky pro začínající stranické historiky s názvem Úvod do studia dějin KSČ, která byla publikována v roce 1962. Pokud přičteme oslabení stavu katedry o pět pedagogických a vědeckých pracovníků (Bartošek, Pichlík, Kořalková, Hejda, Šauer) v rámci již výše popsané katedrové čistky v roce 1958, stává se zjištění, že v inkriminovaných čtyřech letech nebyl publikován žádný text většího rozsahu, poněkud méně překvapivým.

34 J. KLAdiva (ed.), Úvod do studia dějin KSČ, Praha 1962.

35 Zdeněk KÁRNík, O poměru levice německé sociální demokracie ke komunistickým skupinám v severních Čechách v roce 1919, ZK 1/1, 1958, s. 48-56; TÝŽ, Počátky marxistické levice (K 40. výroči vzniku marxistické levice), С̆s ̌̌H 7/6, 1959, s. 644-675; TÝž, Prvni samostatné vystoupení marxistické levice (5.-6. ř́jen 1919), ZK 2/1, 1959, s. 15-38; TÝž, Úloha politické literatury v ideologickém boji revolučního dělnického hnutí v českých zemích (1919-1920), in: K některým otázkám ideového vývoje dělnického hnutí v našich zemích (Acta Universitatis Carolinae - Philosophica et Historica, dále AUC-PhH 1/1960), s. 23-37; TÝž, Založeni KSČ v severovýchodních Čechách 1917-1921, Havlíčkův Brod 1961; Koloman GAJAN - Zdeněk KÁRní, Boj za utvorenie KSČ, Bratislava 1961; Zdeněk KÁRNí, Revoluční hnuti v českých zemích v obdobi frontálního útoku české buržoazie (záři - prosinec 1920), in: O revoluční jednotu československého dělnického hnutí (AUC-PhH 1961/5), s. 21-46; TÝž, Za československou republiku rad. Národní výbory a délnické rady v českých zemích 1917-1920, Praha 1963; Vladimír DuBSKÝ - Zdeněk KÁRNí, Otázka masovosti strany v boji za vytvoření KSČ, PD KSC̆ 1961/2, s. 180-205; Vladimír DuBSKÝ, K otázce centrismu v československém dělnickém hnutí v období boje za vytvoření KSČ, ZK 2/1, 1959, s. 1-14; Vladimír KAší, Osobnost Leninova v českém sociálně demokratickém tisku v roce 1917, ZK 1/1, 1958, s. 40-48; TÝž, Snahy o jednotnou reformistickou stranu v letech 1917-1918 a jejich porážka (Příspěvek $k$ otázce formování marxistické levice v českém dělnickém hnutí), Praha 1961; Jan MĚCHÝr̆, Hornický sever s komunisty. Přispěvek k založení KSČ v severozápadních Čechách, Liberec 1961. 
dělnické tř́ídy, a anarchokomunismem, stavícím se proti jakékoliv formě politické organizace, představovaly hlavní nebezpečí na levici. Na tuto etapu v řadě studií chronologicky navazovalo zpracování problematiky dvacátých a počátku třicátých let, byt' ne v ucelené podobě. ${ }^{36}$ Jedná se o období tzv. konsolidace kapitalistického systému, vyznačující se soupeřením Jílkovy skupiny (Bolen, Houser, Vajtauer), která svými ultralevými a sektářskými tendencemi působila na dělnické hnutí rozkladným způsobem, s tzv. zdravým bolševickým jádrem, tvořeným skupinou kolem Klementa Gottwalda (Šverma, Dolanský, Kopecký, Köhler a další), které se začalo hlasitě dožadovat bolševizace strany, aktivizace dělnické tř́ídy na základě jednotné fronty a brzké perspektivy socialistické revoluce. Klíčovým mezníkem této etapy se stalo vítězství bolševického směru na V. sjezdu KSČ v roce 1929, který je jakýmsi bodem obratu všech soudobých narativů na cestě k budoucí proletářské revoluci. V souvislosti s V. sjezdem strany stojí za zmínku především článek Vladimíra Dubského, který se jeví v rámci stranické historiografie jako poměrně progresivní a po mém soudu předznamenává některé základní interpretační teze, které byly typické pro reformní dějepisectví v šedesátých letech. Jedná se zejména o kritiku V. sjezdu v otázce nediferencovaného př́stupu $\mathrm{k}$ chápání vztahu buržoazní diktatury a fašismu a $\mathrm{v}$ otázce teorie sociálfašismu, jež ve stranickém dikursu sloužila k označení soupodstatnosti sociální demokracie s fašizující buržoazii. ${ }^{37}$ Také Dubského obhajoba Šmeralovy koncepce masové strany, která byla V. sjezdem označena za ucelenou soustavu oportunistických názorů a ideový zdroj všech oportunistických chyb strany, vyznívá poměrně progresivně. Problematikou třicátých let se v tomto období na katedře nikdo soustavněji nezabýval. Samostatným tématem meziválečného období byly otázky odborového hnutín ${ }^{38}$ a rolnické problematiky. ${ }^{39}$

36 Vladimír DuBskÝ, Historický význam V. sjezdu KSČ, ČsČH 7/1, 1959, s. 1-24; TÝž, Ultralevé tendence v Komunistické straně Československa v letech 1921-1922 a boj za jejich překonání, in: K některým otázkám ideového vývoje dělnického hnutí v našich zemích (AUC-PhH 1/1960), s. 39-61; Lubomír VejnAR, Stupeň vykořistování horníků v severočeském a ostravském uhelném revíru za předmnichovské republiky, ZK 1/1, 1958, s. 63-69; TÝž, Od oportunistické pasivity k bolševické aktivitě, NM 13/2, 1959, s. 142-155; TÝž, Boj KSČ proti brněnské pravicové skupině v letech 1924-1930, in: K některým otázkám ideového vývoje dělnického hnutí v našich zemích (AUC-PhH 1/1960), s. 63-86; TÝž, Československá sociálni demokracie a taktika jednotné fronty na počátku třicátých let, in: O revoluční jednotu československého dělnického hnutí (AUC-PhH 1961/5), s. 73-92; Lubomír VEBR - Lubomír VeJNAR, Etapa bojové cesty (K třicátému výroči mostecké stávky), NM 16/4, 1962, s. 446-456; Květa KoŘalkovÁ, Ohlas hnutí nezaměstnaných ve vnitropolitickém životě Československa na počátku hospodářské krise (1930-1931), Čs ČH 6/4, 1958, s. 470-500.

37 V. DuBský, Historický význam V. sjezdu KSČ, s. 1-24. Je ovšem nezbytné připustit jistou obezřetnost v této otázce, nebot' jsem se zabýval pouze stranickou historiografií na katedře dějin KSČ, a tak je možné, že teze, které se zdají v rámci katedrové produkce progresivní, se mohly objevovat v tomto období i u jiných stranických historiků z jiných stranických ústavů, které jsou mimo záběr zde předkládané práce.

38 Vladimír DuBSKÝ, Vývoj revoluční opozice v odborovém sdružení československém v roce 1921, ZK 1/1, 1958, s. 57-63; TÝž, Založení Rudé odborové Internacionály a její vliv na vývoj odborového hnutí v ČSR počátkem 20. let, Čs ̌̌H 9/4, 1961, s. 473-494; TÝž, Počátky boje Komunistické strany Československa za revolučni orientaci dělnického odborového hnuti v Československu, in: O revoluční jednotu československého dělnického hnutí (AUC-PhH 1961/5), s. 47-72; Lubomír VEJNAR, Revoluční nástup rudých odborů 1929-1930, Praha 1962.

39 Lubomír VEBR, K vymezení charakteru zemédělských stávek v predmnichovském Československu, ZK 1/1, 1958, s. 70-81; TÝž, Úsilí KSČ o řešení rolnické otázky na počátku třicátých let, in: K některým otázkám ideového vývoje dělnického hnutí v našich zemích (AUC-PhH 1/1960), s. 87-98; TÝž, Komunistická strana Československa a rolnická otázka v kapitalistickém Československu, in: O revoluční jednotu československého dělnického hnutí (AUC-PhH 1961/5), s. 127-150; Viliam Plevza - Lubomír VeBR - Samuel CAmBel, KSČ a rolnicka otázka na Slovensku (1921-1960), Bratislava 1961. 
Otázce dělnického hnutí do první světové války se v tomto období věnoval zejména Jan Měchýřr. 40 Jeho hlavním tématem byl rozkol dělnického hnutí na umírněné a radikály v osmdesátých a devadesátých letech devatenáctého století, který Měchýř považuje za zákonitý a nevyhnutelný, nebot' teprve v tomto rozštěpení získává dělnická třída nezbytné zkušenosti do budoucna. Nově se formující radikální frakce představovala nebezpečí v podobě anarchistických tendencí, které se projevovaly zejména zásadním odmítnutím jakékoliv participace na probíhajících politických bojích a bránily vytváření masových stran proletariátu. Ovšem s odkazem na Leninovu tezi, že anarchismus je trestem za oportunistické hříchy sociální demokracie, nachází Měchýř i jistá pozitiva na působení anarchistického hnutí, především v určitém vyvažování reformistických tendencí umírněné frakce v dělnickém hnutí. Doplňkem k tomuto tématu byl spíše teoreticky pojatý článek Vladimíra Kašíka, zabývající se problematikou jednoty v dělnickém hnutí před první světovou válkou. ${ }^{41}$ Jednotu dělnického hnutí Kašík nazírá jako vztah tří základních a vzájemně provázaných složek - jedná se o jednotu politické strany s dělnickou třídou a pracujícím lidem. Vyvrcholením etapy bojů za jednotu v mezinárodním dělnickém hnutí pak byl vznik Internacionály, jež se zároveň stala výchozím bodem pro artikulaci vlastních zájmů proletariátu, který si uvědomil, že je zvláštní společenskou třídou. Marxistickou terminologií došlo k přerodu třídy o sobě v třídu pro sebe.

Jen okrajová pozornost byla (s výjimkou Jaroslava Kladivy) věnována dějinám po druhé světové válce. ${ }^{42}$ Kladivovým problémem bylo, že více než erudovaným historikem byl spíše jen propagandistou a stranickým ideologem (člen ÚV KSČ), což se projevilo na jeho textech, věnovaných kulturní revoluci a ideologii měrou více než dostatečnou. ${ }^{43}$

\section{Období reformního diskurzu (1963-1970)}

Otázka sloučení kateder dějin KSČ a dějin SSSR a KSSS, o které se příležitostně diskutovalo již od konce padesátých let, začala nabírat jasnějších obrysů v první polovině roku 1963, kdy bylo rozhodnuto, že od konce roku se bude v rámci výuky marxismu-leninismu v prvním ročníku na všech fakultách povinně vyučovat nový předmět dějiny mezinárodního dělnického hnutí a KSČ. Díky určitému zpoždění došlo ke sloučení až uprostřed školního

40 Jan MĚchÝr̆, $K$ dosavadním názorům na rozkol dělnické strany v našich zemích na počátku 80. let minulého století, ZK 1/1, 1958, s. 15-21; TÝŽ, Chicagská , Budoucnost“ (1883-1886) a jeji pưsobení v našem dělnickém hnutí, ZK 2/1, 1959, s. 39-48; TÝž, K podstatě spori̊ v našem dělnickém hnutí v osmdesátých letech minulého století, in: K některým otázkám ideového vývoje dělnického hnutí v našich zemích (AUC-PhH 1960/1), s. 5-22; TÝž, Hornický sever.

41 Vladimír KAšík, Úvodem $k$ otázce jednoty v dělnickém hnutí před vznikem komunistických stran, in: O revoluční jednotu československého dělnického hnutí (AUC-PhH 1961/5), s. 7-20.

42 Jaroslav KLadiva, Poznámka k vymezení náplně a etap kulturní revoluce v lidově demokratickém Československu, ZK 1/1, 1958, s. 105-107; TÝŽ, Patnáct let lidově demokratického Československa, ZK 3/1, 1960, s. 1-20; TÝž, 15 let lidově demokratického Československa, Čs ̌̌H 8/5, 1960, s. 621-635; TÝŽ - L. VEJNAR, Historický mezník ve vývoji našich národi̊, NM 15/5, 1961, s. 536-547; Jaroslav KLADIVA, Obsah a pojeti socialistické kulturní revoluce, NM 15/10, 1961, s. 1191-1201; TÝž, Vědeckotechnický pokrok a kádry, NM 17/1, 1963, s. 43-52; Ladislav NiKLíčEK - Josef MichŇÁK, Přispěvek k historii mládežnického hnutí v ČSSR (Boj za jednotu mládeže v letech 1945-1949), Praha 1962; Jan MĚcHÝŘ, Vytvoření jednoty pracujících v Československu v letech 1945-1948, in: O revoluční jednotu československého dělnického hnutí (AUC-PhH 1961/5), s. 151-191.

43 V tomto směru zaujme snad jen Kladivovo tvrzení, že již v prosinci 1953 na zasedání ÚV KSČ k ideologickým otázkám došlo ke kritice kultu osobnosti. J. KLADIVA, 15 let lidově demokratického Československa, s. 627. 
roku v únoru 1964. Vedoucím nově vzniklé katedry dějin dělnického hnutí se stal Jaroslav Kladiva. Nově př́ichozími z katedry dějin SSSR a KSSS byli Jaroslav Procházka, Vladimír Suchopár, František Hrbata, Zdeněk Uherek, Jiřina Červinková, Jaroslava Pelikánová a Vlastimila Křepeláková. Zároveň byly převzaty pedagogické a vědecké úkoly obou kateder. K významnější personální obměně došlo hned následujícího roku 1965, kdy byl Lubomír Vebr převeden na nově osamostatněnou katedru pomocných věd historických ${ }^{44}$ a kdy po dlouhé nemoci (rakovina) v červnu zemřel Lubomír Vejnar. Náhradou nastoupili na katedru jako odborní asistenti Jiří Muška a Jan Kuklík. Počátkem roku 1967 odešel do důchodu již sedmdesátiletý Jaroslav Procházka a na jeho místo byl vybrán mladý absolvent oboru dějin dělnického hnutí Pavel Seifter.

Již v první polovině roku 1965 došlo ze strany fakultního vedení k útoku na samostatnost oboru dějiny dělnického hnutí, a tím i na samotnou existenci katedry. Podle nové nomenklatury předmětů $\mathrm{v}$ oblasti sociálních věd pro školní rok 1965/1966 byl obor dějiny dělnického hnutí jako samostatný studijní směr zrušen. Tyto útoky se pak opakovaly po celý zbytek šedesátých let, kdy napríklad v roce 1968/1969 byl obor vedením fakulty vyřazen ze seznamu studijních oborů oprávněných prijímat nové uchazeče. Tato situace se definitivně vyřešila až zrušením katedry v období nastupující normalizace, kdy za hlavní viníky neutěšeného stavu a reformního vývoje fakulty v druhé polovině šedesátých let byly novým normalizačním vedením označeny především katedry marxismu-leninismu, mezi něž byla počíána i katedra dějin dělnického hnutí. Z členů katedry patřili mezi nejkritizovanější osoby zejména Jaroslav Kladiva a Zdeněk Kárník. Vedoucí katedry Jaroslav Kladiva, který byl v letech 1966-1970 zároveň děkanem fakulty, byl nařčen, že svou činností v letech 1968-1969 přešel na pozice pravicového oportunismu. V polovině ledna sám rezignoval na funkci děkana, pravděpodobně po nátlaku kolegů z ÚV KSČ. Druhou velmi exponovanou osobou katedry se ve fakultním dění stal Zdeněk Kárník, který byl předsedou stranické rehabilitační komise, členem státní rehabilitační komise a také členem a pozdějším místopředsedou fakultního celozávodního výboru KSČ. Z rozhodnutí rektora byly k 15 . dubnu 1970 zrušeny katedry dějin dělnického hnutí, politologie a srovnávací literatury. Na katedře dějin dělnického hnutí se propuštění týkalo Jaroslava Kladivy, Vladimíra Kašíka, Zdeňka Kárníka, Jiřího Mušky, Ladislava Niklička a Pavla Seiftera. Vladimír Dubský, Vlastimila Křepeláková, Zdeněk Uherek a Jan Kuklík byli převedeni na katedru československých dějin, František Hrbata přešel do Střediska iberoamerických studií FF UK.

I v tomto období se objevilo několik př́spěvků metodologického charakteru (Kaplan, Macek, Křen, Pavel a Michal Reimanové) a do diskuse z katedrových historiků zasáhli také J. Měchýř s L. Niklíčkem; ve všech př́ípadech se ale po mém soudu jednalo o již jednou řečené. ${ }^{5}$ Většina argumentů byla jen ozvěnou metodologických diskusí z konce padesátých let, byt' možná v poněkud podrobnější a radikálnější podobě. Jsem toho názoru, že tyto príśsp̌vky budí dojem jisté deziluze z nenaplněných očekávání, která právě diskuse po

44 Až do roku 1964 byly pomocné vědy historické oddělením katedry československých dějin, viz J. HAVRÁNEK a kol., Dějiny Univerzity Karlovy, IV, s. 456.

45 Karel KaPLAN, Aktuálni úkoly dějin KSČ, NM 17/1, 1963, s. 62-70; Josef MACEK, Naléhavé problémy historické védy, NM 17/9, 1963, s. 1043-1051; Pavel ReImAN, Úvahy o úkolech historiografie strany po XII. sjezdu KSČ, PD KSČ 1963/2, s. 163-176; Jan KŘEN - Michal ReIMAN, K syntéze našich novodobých dějin, PD KSČ 1963/2, s. 208-226; Jan MĚCHÝR - Ladislav NIKLÍ̌̌EK, O problémech vývoje historiografie československého dělnického hnutí po únoru 1948, PD KSČ 1964/1, s. 60-71; Jan KŘEN, K metodickým otázkám modernich dějin, PD KSČ 1966/3, s. 323-351. 
XX. sjezdu vyvolala, a proto bylo třeba je znovu opakovat v poněkud radikálnější podobě, aby konečně došly naplnění a stranická historiografie se stala skutečnou vědou s jasně formulovaným teoreticko-metodologickým aparátem. $\mathrm{V}$ tomto směru se mi jeví př́značné tvrzení Karla Kaplana: „Di̊sledky kultu osobnosti v historii strany a v praxi historiků byly postupně prekonávány. Zvláště od r. 1956, od XX. sjezdu KSSS se tento proces vyvijel rychleji. Uvolnily se tvưrči sily historiků a vzniklo několik velmi podnětných a cenných historických prací, na mnoha dalšich se pracuje. Avšak proces zdaleka neskončil."“46 Kaplan jasně naznačuje, že v historické vědě se stále navazuje na procesy zahájené po roce 1956, a nejedná se o nové metodologické př́istupy, vyvolané počínající společenskou liberalizací $\mathrm{v}$ roce 1963.

Z hlediska katedry byly důležitější debaty týkající se dějin mezinárodního dělnického hnutí, na které začal být $\mathrm{v}$ šedesátých letech kladen podstatně větší důraz než $\mathrm{v}$ předchozím období. Snaha zasadit domácí dějiny do mezinárodního kontextu byla očividná. K této problematice bylo na přelomu let 1962-1963 uveřejněno několik teoretických statí. ${ }^{47}$ Publikované články byly prosty polemického tónu, jednalo se spíše o navzájem se doplňující př́spěvky, což bylo celkem pochopitelné, nebot' nebyly kritickou diskusí nad pracemi minulého období, nýbrž vytyčovaly budoucí úkoly stranické historiografie na poli dějin mezinárodního dělnického hnutí. Z jednotlivých tezí zaujme varování Milana Hübla před metodologickým nacionalismem, který se projevoval jednak jako nacionalismus český a slovenský, ignorující se navzájem, jednak jako nacionalismus československý, nahlížející historické fenomény z československé perspektivy a považující je za jedinečné. Budoucí člen katedry Vladimír Suchopár přispěl svým holistickým př́stupem, zdůrazňujícím, že celek má vždy hlubší význam, než prostý součet jednotlivých částí, nebot' disponuje specifickými kvalitami a vnitřními zákonitostmi, které nikdy v jeho jednotlivých částech nejsou k nalezení. Nejzajímavější je z našeho pohledu př́spěvek Miloše Hájka. Teorie marxismu-leninismu a Leninovy výroky jsou pro něj základním východiskem a předpokladem správného badatelského př́stupu, nikoliv však jeho automatickou zárukou, nebot' záruka před omylem neexistuje. S odvoláním na Lenina připouštěl v určitých dílčích aspektech možnost existence plurality správných pohledů. $\mathrm{V}$ tomto místě popisuje charakteristický rys stranické historiografie $\mathrm{v}$ druhé polovině šedesátých let: připuštění určité plurality pohledů v dílčích aspektech, ovšem při nepochybném primátu teorie marxismu-leninismu, jež při správné aplikaci vede $\mathrm{k}$ jedinému možnému poznání pravdy a napomáhá tím $\mathrm{k}$ utváŕení správné politické linie strany.

V tomto období byly na katedře publikovány dvě kolektivní práce. Jako první Úvod do dějin dělnického hnutí, ${ }^{48}$ který byl přepracovanou verzí nepř́liš povedeného Úvodu do dějin KSČ z roku 1962. Lze konstatovat, že se jednalo o mnohem kvalitnější príručku, plnící úlohu tolik požadované vysokoškolské učebnice. Z pozitiv práce je možno kvitovat,

46 K. KaPlan, Aktuální úkoly dějin KSČ, s. 64.

47 Milan HüBL, Historiografie mezinárodního dělnického hnutí v současnosti, PD KSČ 1962/5, s. 685-704; Zdeněk BRADÁČ - Vladimír SuCHOPÁR - Pavel ReIMAN - Zdeněk Šolle, O některých otázkách dějin mezinárodního délnického a komunistického hnutí. K článku M. Hübla, PD KSČ 1963/1, s. 61-80; Růžena HaVRÁNKOVÁ Jaroslav VALENTA - Milan OTÁHAL, K aktuálním úkoli̊m v historiografii mezinárodního dělnického hnutí, PD KSČ 1963/2, s. 227-234; Milan ŠvANKMAJER, K otázkám kolektivnich metod historické práce, PD KSC̆ 1963/4, s. 566-569; Miloš HÁJEK, K některým problémům boje proti dogmatismu v historiografii mezinárodního dělnického hnutí, PD KSČ 1963/5, s. 730-739.

48 Vladimír DuBSKÝ et alt., Úvod do déjin délnického hnutí, Praha 1966. 
že vedle takřka svaté trojice klasiků Marxe, Engelse a Lenina doporučuje i pozorné studium dalších významných marxistických teoretiků, jakými byli Georgij Plechanov, Paul Lafargue, Antonio Labriola, Antonio Gramsci a dokonce i Karl Kautsky. Avšak ani dílo Marxe, Engelse a Lenina není pro autory učebnice neměnným kánonem či jakýmsi uzavřeným systémem věčných pravd. Navrhují přistupovat k jejich dílu s kritickým duchem, nebot' jinak hrozí opětovné nebezpečí dogmatismu. Doporučují také studium dříve zavrhované buržoazní historiografie, nebot' „, pera představitelů těchto proudů buržoazní historiografie vycházejí často pozoruhodné soudy a zajímavé postřehy, zvláště v těch oblastech, které zůstávaly $v$ di̊sledku některých nesprávných hledisek a představ delši dobu mimo pozornost marxistické historiografie “. ${ }^{49} \mathrm{~V}$ některých formulacích můžeme dokonce vytušit i skutečnou obeznámenost autorů s některými koncepty západní historiografie. Objevují se např́klad náznaky recepce strukturálního př́stupu školy Annales a Braudelova dlouhého trvání..$^{50}$

Druhou kolektivní prací katedry se stala syntéza dějin mezinárodního dělnického hnutí. ${ }^{51}$ Jednalo se o celkem přehlednou príručku, jejímž kladem je relativní redukce prostoru věnovaného vývoji v Rusku, potažmo v Sovětském svazu. Pozornost je naopak věnována národněosvobozeneckým bojům a formování dělnického hnutí v zemích třetího světa, což bylo v dané době novum. Předností je i velmi podrobně zpracovaný jmenný rejstř́k všech významných osobností dělnického hnutí, obsahující také jejich stručnou charakteristiku. Podle ohlasu na stránkách stranických časopisů se dá soudit, že učebnice splnila své poslání a stala se vítanou pedagogickou pomůckou. Přesto je logické, že tato syntéza v podstatě shrnovala tehdejší stav bádání o mezinárodním dělnickém hnutí a nečinila si žádné nároky na nové interpretace či výkladové vzory.

V souvislosti s problematikou mezinárodního dělnického hnutí se hlavní pozornost na katedře soustředila na dějiny Kominterny, zejména na utváření jednotné protifašistické fronty v letech 1933-1935. Na tomto tématu se badatelsky profilovali nově př́chozí členové František Hrbata a Vladimír Suchopár, s drobným přispěním Ladislava Niklička. ${ }^{52} \mathrm{Je}$ třeba předeslat, že hlavní viník, jenž bránil utváření jednotné protifašistické fronty, byl vždy spatřován v sociálních demokratech a jejich reformistickém prrístupu, $\mathrm{k}$ čemuž byly sneseny osvědčené argumenty. V období šedesátých let již přesto bylo možno hledat některé dílčí chyby i na straně Kominterny, což znamenalo nový výkladový prvek oproti období předchozímu. Jeden $\mathrm{z}$ kořenů špatného postupu Kominterny byl spatřován v mylné představě o podstatě fašismu, rezultující v chybnou tezi, že všechny buržoazní strany jsou fašistické. Opomenutí leninské teze o diferenciaci uvnitř sociální demokracie podle autorů způsobilo, že řada komunistických předáků chápala boj proti fašismu a proti sociální demokracii jako

49 Tamtéž, s. 17.

50 Tamtéž, s. 28.

51 V. KAšík - V. SuchopÁr (red.), Dějiny mezinárodního dělnického hnutí, Praha 1966.

52 František HrBata, Komunistická internacionála a protifašistické hnutí v letech 1933-1935, Praha 1963; TÝŽ Vladimír Suchopár, Historický mezník. VII. kongres Komunistické internacionály 1935, Praha 1965; František Hrbata - Ladislav NikLíčex, Na cestě k VII. kongresu Kominterny, ČsČH 13/5, 1965, s. 655-682; tiTíž, Naděje a skutečnost. Bezprostřední vliv VII. kongresu Kominterny v mezinárodním dělnickém hnutí, ČsČH 15/5, 1967, s. 667-690; František Hrbata, Opozični směry v mezinárodním dělnickém hnutí a hrozba fašismu v letech

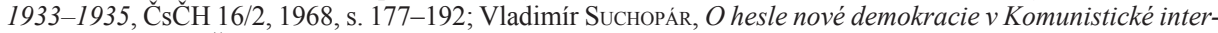
nacionále, PD KSČ 1962/2, s. 163-191; TÝŽ, Komunistická internacionála proti fašismu v letech 1921-1935, Praha 1964; TÝž, Tři fáze v dějinách Komunistické internacionály, PD KSČ 1965/2, s. 217-243. 
totožný, a tak jedinou variantou vytvoření jednotné protifašistické fronty prozatím byla likvidace a pohlcení dělnictva sociálnědemokratických stran.

Zásadním katedrovým prríspěvkem k postupující liberalizaci stranické historiografie konce šedesátých let jsou texty Ladislava Niklíčka, zkoumající vývoj strany ve třicátých letech. ${ }^{53}$ Domnívám se, že Niklíčkovy texty se dostaly na hranici př́ipustné kritiky, která byla $\mathrm{v}$ tomto období ve stranické historiografii možná, a proto si zaslouží trochu více pozornosti. Ladislav Niklíček nahlíží Gottwaldovské vedení strany jako rozštěpené, byt' nezastírá, že všichni bez rozdílu měli víru v politiku Sovětského svazu a Kominterny. Zde se nabízel jeden z možných výkladových momentů použitelný i na politickou situaci konce šedesátých let, pro niž bylo charakteristické soupeření reformních a konzervativních sil, kdy byla obhajována specificky československá koncepce cesty k socialismu v opozici k slepému následování cesty sovětské. Taktika jednotné protifašistické fronty však byla pouze demagogickým úskokem, který měl převést reformistické dělníky pod komunistická hesla za nastolení diktatury proletariátu a sovětské moci v Československu. L. Niklíček s nebývalou otevřeností konstatuje: ,i volnějši uplatnění taktiky VI. kongresu Kominterny bylo charakterizováno otevřeným hegemonismem a určitým , mesiášstvím 'komunistů, bezpochybným přesvědčením, že komunisté už proto, že jsou komunisty, jsou ,uvědomélejši ' než nekomunisté a že jsou povoláni k tomu, aby úspěšně a permanentně presvědčovali ty dělníky, kteři nejsou členy komunistické strany" ${ }^{54}$ Se štěpením stranického vedení ve třicátých letech je úzce svázáno hodnocení úlohy Josefa Guttmanna, jenž byl stranickou historiografií dlouhou dobu zatracován jako zrádce, oportunista a renegát. Důvodem k tomuto hodnocení byla Guttmannova kritika politiky Kominterny v Německu, která svou chybnou strategií usnadnila nástup nacismu. Po následné denunciační kampani ovšem J. Guttmann kritiku i sebekritiku odmítl, za což byl bezpodmínečně vyloučen ze strany. V Guttmannově kauze nachází Niklíček již zárodky deformací, které se v plné míře projevily ve vykonstruovaných politických procesech po roce 1948. „Proti Guttmannovi byla okamžitě ve straně rozvinuta kampan̆, při níž často účel světil prostředky a v níž ani tak nešlo o skutečnou ideologickou diskusi, jako o osobni diskreditaci člověka, který se postavil ,jediné pravdivé linii‘. Ve třicátých letech Gottwaldovo vedení KSČ poprvé uvedlo do chodu mechanismus, který za necelých dvacet let nelikvidoval své oběti jenom ,politicky'"“55

Při hodnocení Josefa Guttmanna se nabízí ideální možnost ukázat, jak se vyvíjel pohled na jeho kauzu ve stranické historiografii, alespoň z pohledu katedry dějin dělnického hnutí v šedesátých letech. Ještě František Hrbata ve své práci z roku 1963 činí Guttmanna vinným z rozbíjení úspěšného boje za vytvoření jednotné fronty a vidí v něm šiřitele poraženeckých nálad. Článek, který uveřejnili Niklíček s Hrbatou v roce 1965, se omezuje pouze na neutrální konstatování, že zhodnocení Gutmannova postupu, které muselo nevyhnutelně skončit jeho vyloučením, je zatím velmi obtížným úkolem. Teprve Niklíčkovy texty z roku 1968, napsané po pádu Novotného vedení, umožnily objektivnější reflexi dané problematiky.

53 Ladislav NiKLíčEK, Za lidovou frontu proti fašismu. I. krajská organizace KSČ v letech zrodu nové strategicko-taktické orientace (1933-1936), Praha 1965; TÝž, Dilema československých komunistů ve třicátých letech, Pardubice 1968; TÝŽ, Vztah KSČ k Československé sociálně demokratické straně dělnické v letech 1932-1933, in: K dějinám Československé sociální demokracie, Praha 1968, s. 82-151; TÝž, Dilema Jana Švermy, Dějiny a současnost 10/1, 1968, s. 15-17.

54 L. NiKLíčEK, Vztah KSČ , s. 97-98.

55 L. NiKLíČEK, Vztah KSČ, s. 146-147. 
Také hodnocení historické úlohy Bohumíra Šmerala z pera Zdeňka Kárníka a Vladimíra Dubského mělo konotace s demokratizačním procesem ve společnosti. ${ }^{56}$ Aktuální byla zejména paralela alternativních cest k dosažení socialismu, nebot' Šmeralova cesta vycházela ze specificky středoevropských tradic demokratického socialismu. Klíčovým se Kárníkovi v tomto směru jeví zejména Šmeralův poválečný myšlenkový vývoj, kladoucí důraz hlavně na koncept masové strany s širokou dělnicko-rolnickou podporou, jež byla v rozporu s bolševickou teorií převzetí moci malou revoluční skupinou. Podle Kárníka se tak začíná vytvářet specificky československá koncepce pokojné revoluce. Pro oba autory byl přitažlivý i Šmeralův koncept dělnické vlády, nebot’ Šmeral pracoval s možností utvoření široce koncipované dělnicko-rolnické vlády se sociální demokracií, která ovšem, a to je nutno zdůraznit, měla tvořit jakousi dočasnou mezifázi na cestě k utvoření diktatury proletariátu. Kárník i Dubský tak vidí ve Šmeralovi zakladatele československé varianty demokratického komunismu, který ovšem spěl k naprosto odlišnému pojetí socialistické revoluce, než byla revoluce sovětského typu, jež zvláště po Leninově smrti začala vykazovat značně dogmatické rysy. B. Šmeral, pokud nechtěl být z komunistického hnutí exkomunikován, se musel své varianty demokratického komunismu vzdát. Ovšem spojnice vedená mezi Šmeralovým konceptem a „,socialismem s lidskou tváří“ na konci šedesátých let je pro Kárníka neoddiskutovatelná.

V roce 1965 vydala katedra kolektivní práci, zaměřenou na problematiku sociálnědemokratického reformismu, ${ }^{57}$ jež svou poměrně radikální dikcí naznačila meze reformního dějepisectví v polovině šedesátých let. Zajímavé srovnání nabízí text Františka Hrbaty 58 s jeho dalšími díly z let 1963-1965, věnovanými mezinárodnímu dělnickému hnutí, které se očividně nesly v mnohem smír̆livějším tónu. Domnívám se, že vysvětlení této diskrepance se nachází v možnostech rozdílného hodnocení domácího a mezinárodního dění ve stejném období. Jak již bylo naznačeno, rozchod se stalinským kultem osobnosti a kritika ultralevého sektářství a dogmatismu, které hrály dominantní roli v mezinárodním dělnickém hnutí, byly již několik let součástí standardního narativu, a proto straničtí historikové mohli volit ve vztahu k sociálnědemokratické internacionále relativně umírněný tón. Oproti tomu stejně umírněný tón $\mathrm{v}$ otázce reformistického vlivu v dělnickém hnutí na domácí půdě by v tomto období přivedl Hrbatu k rozchodu s osobou Klementa Gottwalda a jeho „karlínskými kluky“, což až do pádu Antonína Novotného nebylo myslitelné.

Koncem šedesátých let se díky Janu Kuklíkovi začala na katedře řešit také otázka levicových proudů za druhé republiky a na počátku protektorátu, byt' zatím jen v zárodečné podobě. ${ }^{59}$ Klíčovou otázkou československého vývoje v letech 1945-1948 se na katedře zabýval

56 Zdeněk KÁRní, První pokus o založení komunistické strany v Čechách, Praha 1966; TÝž, Socialisté na rozcestí. Habsburk, Masaryk či Šmeral?, Praha 1968; TÝž, Založení KSČ a Kominterna, Revue dějin socialismu (dále RDS) 9/2, 1969, s. 163-201; Vladimír DuBskÝ, Utváření politické linie KSČ v obdobi Šmeralova vedení, PD KSČ $1967 / 5,6$, s. 645-668, 803-838.

57 František ČERVINKA et alt., O reformismu v českém dělnickém hnutí, Praha 1965. Jako autoři přispěli Červinka, Kárník, Vejnar, Hrbata, Měchýř. František Červinka jako jediný nebyl členem katedry dějin dělnického hnutí.

58 František Hrbata, Úloha československého reformismu v protifašistickém boji dělnictva (1933-1938), in: O reformismu v českém dělnickém hnutí, Praha 1965, s. 171-269.

59 Jan Kunlí, Poznámky k činnosti „Skupiny Délnické akademie“ v druhé polovině třicátých let z hlediska geneze PVVZ, in: Odboj a revoluce - zprávy (Př́loha) 5/2, 1967, s. 50-68; TÝž, Poznámky k činnosti sociálních demokratů ve druhé republice, in: K dějinám československé sociální demokracie, Praha 1968, s. 191-257; TÝž, Petiční výbor věrni zůstaneme v obdobi Mnichova a za druhé republiky, ČsČH 17/5, 1969, s. 681-711; Jan KuKLík - Pavel ZÁtKa, Spisovatelský manifest a Petiční výbor „,Věrni zůstaneme!“, RDS 9/2, 1969, s. $203-225$. 
povýtce pouze Jaroslav Kladiva, ale zaměřil se především na otázku kulturní revoluce. ${ }^{60}$ Vývoj dělnického hnutí v devatenáctém století měl v reformním dějepisectví spíše okrajové postavení. Této problematice se na katedře věnovali Vladimír Kašík a Jan Měchýŕ. ${ }^{61}$ Právě menší ideologická exponovanost daného tématu však umožnila oběma autorům napsat jedny z nejkvalitnějších prací za celou dobu existence katedry. Kritický přístup k vývoji dělnického hnutí v tomto období mohl konvenovat s názorem stranického vedení, že právě neexistence revoluční strany zapř́činila spoustu chyb, a tím ospravedlnit její vznik. Kašík poukazuje zejména na dvě základní chyby, které se pravidelně objevovaly v předchozích zpracováních tohoto tématu. Za první chybu považuje př́liš jednostranný vztah mezi Internacionálou a marxismem, kdy jiné neméně vlivné teorie byly nemístně marginalizovány (Pierre-Joseph Proudhon, Ferdinand Lassalle, Michail Bakunin), což vedlo k značnému přeceňování vlivu marxistické teorie na dělnické hnutí v jeho raných fázích vývoje. Varující je podle něj také př́liš jednostranné vnášení teorie do dělnického hnutí, což pak má za následek, že se teorii chybně připisuje úloha aktivního činitele a naopak dělnické hnutí je odsouzeno do pozice pouhého pasivního recipienta této teorie. „Chtěl bych v této souvislosti vyslovit domněnku, že právě toto pojetí procesu tzv. vnášeni teorie do hnutí a s ním spojené zjednodušené pojetí dějin Internacionály (a přirozeně nejenom dějin I. internacionály) mèlo př́mou souvislost s chápáním marxistické teorie, vztahu teorie a dělnictva, pomèru marxismu k jiným myšlenkovým proudi̊m v tzv. období kultu osobnosti a že i dnes je výrazným rysem dogmatismu." 62

Vývoj dělnického hnutí naopak na domácí půdě reflektoval Jan Měchýŕ. ${ }^{33}$ Jeho práce asi nejvíce naplňují představu sociálních dějin viděných zdola, nebot' pracuje s řadou statistických ukazatelů, vztahujících se k severočeskému hornickému revíru, a tak se čtenář může v úvodu knihy obeznámit s vývojem produkce uhlí či rozborem vlastnických poměrů, $\mathrm{s}$ vývojem zaměstnanosti, intenzitou práce a délkou pracovní doby, mzdovými či bytovými poměry nebo také s problematikou úrazovosti. Jednu kapitolu dokonce věnuje určité snaze o postižení kolektivní hornické mentality utvářené specifickým charakterem práce a podporující hornickou solidaritu a soudržnost. Lze shrnout, že stávka v autorově podání znamenala kvalitativní přelom ve vývoji dělnické tř́́dy v českých zemích, nebot' ta byla poprvé schopna jasně artikulovat své tř́ídní požadavky a uskutečnila tak přechod z třídy o sobě ke tř́íě pro sebe. Zajímavý je také závěr knihy, kde s největší pravděpodobností nalézáme mezi odsudky politických procesů s dělnickými předáky také odsudek politických procesů z první poloviny padesátých let.

60 Jaroslav KLADIVA, Kulturní a ideologická činnost KSČ v obdobi jejiho VIII. sjezdu, PD KSC̆ 1965/4, s. 531-554; TÝž, Problematika kulturní revoluce v sovětské historiografii, ČsČH 13/2, 1965, s. 165-179; TÝž, Boj o duši národa v předvečer února 1948, ČsČH 15/1, 1967, 51-71; Tŕ̌̌, Kultura a politika (1945-1948), Praha 1968.

61 Vladimír KAší, Dějiny Internacionály a některé problémy marxistické historiografie, PD KSČ 1965/1, s. 85-102; тÝž, Dějiny První internacionály, Praha 1965; тÝž, Bakunin, Praha 1969.

62 V. KAšíK, Dějiny Internacionály, s. 94.

63 Jan MĚcHÝŘ, Neodvisli socialisté v českém dělnickém hnutí na počátku 90. let XIX. století, ČsČH 13/2, 1965, s. 180-201; TÝž, Počátky dělnického hnutí na hornickém severu, Praha 1967. 


\section{Závěr}

Závěrem lze konstatovat, že psaní stranických dějin na katedře dějin KSČ v první polovině padesátých let po obsahové ani formální stránce nikterak nevybočilo ze soudobého diskurzu stranické historiografie. Nově utvářené historické narativy musely odpovídat na politické a společenské požadavky dané doby, artikulované stranickým vedením a tlumočené obci historiků nově zř́zeným Ústavem dějin KSČ, jenž se stal na celých dvacet let dominantní institucí na poli stranické historiografie. Vyhrocené politické kampaně, probíhající politické procesy, stávky a nepokoje vyžadovaly hledání a odhalování nepřátel a zrádců vně i uvnitř strany. Tomu odpovídala i dikce, která se vyznačovala radikálním slovníkem a poměrně jednoduchou tezovitostí, srozumitelnou širokým vrstvám společnosti, a tudíž prakticky využitelnou pro rozsáhlou politickou propagandu. Při odhalování jak vnějších nepřátel v podobě západního imperialismu a kapitalismu, tak i nepřátel uvnitř strany v podobě sociálnědemokratického smýšlení byla aktivní především dvojice mladých historiků Karel Bartošek a Karel Pichlík, kteří vytvořili jedny z propagandisticky nejradikálnějších textů první poloviny padesátých let. Většina členů katedry byla př́slušníky nejmladší generace stranické inteligence (V. Kašík, Z. Kárník, V. Dubský, J. Měchýř, K. Kořalková) a svoji publikační činnost ještě nezahájili.

Období poststalinského diskurzu v letech 1956-1963 znamenalo jednoznačný posun ve stranické historiografii. Můžeme mluvit o proto-revizionistickém či proto-reformním období. Atmosféra nejistoty způsobená XX. sjezdem KSSS, která podnítila řadu metodologických diskusí v marxistické historiografii, se pochopitelně nevyhnula ani katedře dějin KSČ. V rámci třídních prověrek bylo „odejito“ pět členů (K. Bartošek, Z. Hejda, K. Kořalková, K. Pichlík, J. Šauer), což znamenalo značné badatelské oslabení, jež nebylo až do roku 1963 adekvátně nahrazeno. Přesto došlo k nárůstu publikační aktivity, a to díky dozrávání mladé nastupující generace historiků. Zjednodušeně můžeme konstatovat, že volání po zvědečtění stranické historiografie především návratem $\mathrm{k}$ archivním pramenům bylo přes všechny limity a obtíže alespoň zahájeno. Přesto byla stranická historiografie v tomto období nucena obhajovat samu podstatu své existence před útoky historiků obecného zaměření. Do této diskuse se zapojil zejména vedoucí katedry Jaroslav Kladiva svým př́íspěvkem o dialektice navzájem se doplňujících stranických a obecných dějin. Do teoretických diskusí se zapojili také Vladimír Dubský a Vladimír Kašík, prezentující se na svou dobu zajímavým př́spěvkem o dialektickém vztahu dějin a historické osobnosti, jež může $\mathrm{v}$ jistých okamžicích narušit kauzální běh dějin a prosadit svou vůli. Badatelské těžiště katedry bylo zaměřeno na stranické dějiny v meziválečném období, zejména na dobu do V. sjezdu KSČ v roce 1929. Výkladová progrese oproti předchozímu období může být shledávána v jistém - byt' nadále opatrném - pozitivním hodnocení role Bohumíra Šmerala v počátcích vzniku komunistické strany, a naopak v kritice V. sjezdu KSČ v jeho nediferencovaném př́istupu k sociální demokracii, a tím v kritice stalinské teorie sociálfašismu. Splněným pedagogickým úkolem, byt' nepř́liš vydařeným, bylo publikování vysokoškolské učebnice Úvod do studia dějin KSČ. Obecně lze konstatovat, že katedrová produkce v tomto období nevybočila zásadně ze standardů a výkladových schémat diktovaných ve stranické historiografii zejména Ústavem dějin KSČ.

Stále větši důraz na dějiny mezinárodního dělnického hnutí zapříčinil začátkem roku 1964 sloučení s katedrou dějin SSSR a KSSS. Výsledkem byla poměrně solidní syntéza, 
jež mohla sloužit jako základní vysokoškolská učebnice. $V$ druhé polovině šedesátých let nedošlo v teoretické rovině $\mathrm{k}$ žádnému zásadnímu přelomu, spíše se zvýšil důraz na zvědečtění stranické historiografie (zapojili se J. Měchýř a L. Niklíček), což ovšem znamenalo navázání na debaty, které se objevily již po XX. sjezdu v roce 1956. Přesto byl rozchod s dogmatickými výklady padesátých let očividný zejména v některých oblastech. Kritika politiky Kominterny v první polovině třicátých let (F. Hrbata, V. Suchopár) a s tím spjatá obhajoba politických postojů někdejšího renegáta Josefa Guttmanna (L. Niklíček) či pozitivní hodnocení politického myšlení Bohumíra Šmerala s jeho konceptem masové strany (Z. Kárník, V. Dubský). To vše mělo jednoznačné konotace s politickým a společenským procesem reformy v Československu. V těchto historických narativech byly nacházeny předobrazy a legitimizační argumenty samostatné demokratické cesty k socialismu, jež nebyla závislá na dogmatických bolševických vzorech. V řadě textů lze také vysledovat nepř́mou kritiku justiční zvůle, která provázela politické procesy v první polovině padesátých let. Menší politická exponovanost problematiky dělnického hnutí na konci devatenáctého století umožnila napsat jedny z nejkvalitnějších textů, týkajících se jak domácí, tak mezinárodní situace za celou dobu existence katedry (J. Měchýř, V. Kašík).

Určitým překvapivým zjiššnním v oblasti katedrové publikační činnosti za celou dobu její existence je přes neustále proklamované odvolávání se na teorii marxismu-leninismu jen velmi omezené reflektování základní marxistické poučky o základně a nadstavbě. Přestože problematika dělnického hnutí by žádala důkladnou analýzu socioekonomické struktury, opak je pravdou ve většině studií. Kvalitní práce s hospodářskými a sociálními statistikami je spiše výjimkou (s jistým omezením J. Měchýř), naopak důraz na ideologické a politické aspekty, které by měly být součástí jen odvozené nadstavby, dominuje prakticky ve většině prací. To sice může být na jedné straně důsledkem faktu, že práce s ideologickými poučkami je snazší než precizní sociální a ekonomická analýza, na druhé straně to ale může i nechtěně odrážet skutečnou situaci, kdy přes všechny stranické proklamace o vládě dělnické tř́́dy šlo v posledku vždy jen o politické rozhodování úzké stranické elity.

Stranická historiografie se počátkem padesátých let měla stát novým oborem historické vědy, který by sloužil stranickému vedení $\mathrm{k}$ vytváření legitimizačních př́běhů, jež měly usnadnit etablování socialistického režimu. Přes původně propagandistický charakter lze konstatovat, že s postupujícím časem, především v šedesátých letech, byl postupně vypracován vědecký metodologický aparát, který ve spojení s prohloubením archivního výzkumu položil základy relevantnímu historickému bádání, jež samožrejmě i nadále vycházelo z marxistického paradigmatu trrídního boje. Některé texty jsou dodnes součástí doporučené literatury na vysokých školách a leckdy citovány v dnešních odborných monografiích. Týká se to zejména výše zmíněných témat dělnického hnutí před první světovou válkou, stranických dějin v první polovině dvacátých let, problematiky nezaměstnanosti a mezinárodního dělnického hnutí v letech třicátých. Nutno je však přiznat, že cenná je z dnešního pohledu spíše faktografická základna, než interpretační schémata.

Za dobu existence katedry se na ní vystř́ídaly téměř tři desítky historiků, z valné většiny př́slušníků nejmladší generace, která začátkem padesátých let zahajovala svou profesní dráhu. Výsledkem jejich badatelské činnosti se staly tři kolektivní učebnice a přibližně čtyřicet monografií, nepočítaje řadu odborných článků a statí. Na katedře vznikly jak jedny z nejdogmatičtějších textů stalinského období, tak práce, které v období tzv. reformního diskurzu patřily k dobově progresivním a svým důrazem na specificky československou cestu 
k socialismu se hlásily ke společenské demokratizaci konce šedesátých let. Řada členů katedry se také výraznou měrou zapojila do teoreticko-metodologických diskusí o podobě a účelu stranické historiografie po roce 1956. Katedra se tak zařadila, vedle dominantního Ústavu dějin KSČ při ÚV KSČ, po bok katedry dějin KSČ na Vysoké stranické škole (od roku 1965 Vysoká škola politická) a oddělení dějin 19. a 20. století na Historickém ústavu ČSAV, mezi nejvýznamnější pracoviště na poli stranické historiografie a dějin dělnického hnutí v Československu.

\section{JAN CALTA}

\section{Die Parteihistoriographie an der Philosophischen Fakultät der Karlsuniversität in den Jahren 1953-1970}

\section{ZUSAMMENFASSUNG}

Die Parteihistoriographie sollte zu Beginn der 1950er Jahre eine neue Disziplin der historischen Wissenschaft werden und der Parteiführung zur Schaffung von Legitimationsnarrativen dienen, um die Etablierung des sozialistischen Regimes zu erleichtern. Als Zugang zur Parteihistoriographie haben wir denselben Zugang wie zu einer historischen Wissenschaft gewählt, welche sozial und politisch bedingt war und in ihrer Zeit verbindliche Regeln und Interpretationsschemata aufwies.

Unerlässliche Voraussetzung für das Funktionieren des Faches war die Schaffung eines ausgedehnten institutionalisierten Hinterlandes sowohl in pädagogischer als auch die Forschung betreffender Hinsicht. Beide Funktionen wurden an der Philosophischen Fakultät der Karlsuniversität seit 1953 vom Lehrstuhl für die Geschichte der Kommunistischen Partei der Tschechoslowakei wahrgenommen, welcher 1964 mit dem Lehrstuhl für die Geschichte der UdSSR und der KPdSU zusammengelegt wurde und die beide jetzt gemeinsam den Lehrstuhl für die Geschichte der internationalen Arbeiterbewegung bildeten, welch letzterer sich als erste fachlich ausgerichtete Arbeitsstelle im Bereich der Geschichte der internationalen Arbeiterbewegung profilierte. Im Jahre 1970 wurde der Lehrstuhl als Exponent des reformfreundlichen Kurses der 1960er Jahre von der neuen normalisierungstreuen Fakultätsleitung abgeschafft.

Methodologisch wird die Parteihistoriographie als allmähliche Abfolge von Veränderungen und Verlagerungen des historiographischen Diskurses im Rahmen eines unveränderten marxistisch-leninistischen Paradigmas untersucht. Als entscheidender Wendepunkt erweist sich das Jahr 1956, in dem es zur Kritik des Personenkultes kam und eine allmähliche Wandlung der rigiden historischen Narrative eintrat. Demgegenüber erscheint das oft zitierte Jahr 1963, das als Beginn der gesellschaftlichen Liberalisierung galt, in der Parteihistoriographie keinen Umbruch darzustellen. Der Reformdiskurs knüpfte vielmehr lediglich an die vorausgegangene Epoche an, wenngleich in etwas radikalerer Form. Auf der Grundlage dieser diskursiven Verlagerungen wird die Parteihistoriographie in drei unterschiedliche Zeiträume gegliedert, die freilich nicht strikt voneinander getrennt waren und wo sich zahlreiche Interpretationsschemata und Narrative viele Jahre lang überlappten. Die Jahre 1953-1956 bezeichnen wir als die Zeit des stalinistischen Diskurses, die Zeit von 1956-1963 als die des poststalinistischen (proto-revisionistischen) Diskurses, und schließlich die Jahre 1963-1970 als die Zeit des Reformdiskurses.

Seit seinem Bestehen haben sich am Lehrstuhl fast dreißig Historiker abgewechselt, zum größten Teil Angehörige der jüngsten Generation, die zu Beginn der 1950er Jahre ihre berufliche Laufbahn antraten. Ergebnis ihrer Forschungen sind drei von Autorenkollektiven verfasste Lehrbücher und annährend vierzig Monographien, nicht inbegriffen eine ganze Reihe fachwissenschaftlicher Artikel und Aufsätze.

Was den Anteil des Lehrstuhls für die Geschichte der KPTsch (der Arbeiterbewegung) an der Gestaltung eines neuen historischen Faches betrifft, kann man feststellen, dass er trotz der vorherrschenden Position des Instituts für die Geschichte der KPTsch nicht unerheblich war. Am Lehrstuhl entstanden sowohl einer der dogmatischsten Texte der Stalinzeit (Karel Bartošek, Karel Pichlík) als auch Arbeiten, welche in der Zeit des sog. Reformdiskurses zu den damals progressivsten gehörten und sich in ihrer Betonung des spezifisch tschechoslowakischen Weges zum Sozialismus zur gesellschaftlichen Demokratisierung Ende der 1960er Jahre bekannten. Es handelte sich 
insbesondere um Texte, die sich mit der Person Bohumír Šmerals (Zdeněk Kárník, Vladimír Dubský) oder der Problematik der Herausbildung einer einheitlichen antifaschistischen Front in den 1930er Jahren (Ladislav Niklíček) befassten. Einen nicht unerheblichen Beitrag stellten auch Texte dar, die die Entwicklung der Arbeiterbewegung vor dem I. Weltkrieg skizzierten (Vladimír Kašík, Jan Měchýř), wohingegen die Zeit des Protektorats und die anschließende Entwicklung nach 1945 zu der am meisten vernachlässigten Problematik zählt. Zahlreiche Mitglieder des Lehrstuhls beteiligten sich auch in deutlichem Maße an den theoretisch-methodologischen Diskussionen über Form und Zweck der Parteihistoriographie nach 1956 (Jaroslav Kladiva, Vladimír Kašík, Vladimír Dubský, Jan Měchýř, Ladislav Niklíček).

Deutsche Übersetzung Wolf B. Oerter

Jan Calta

Ústav hospodářských a sociálních dějin FF UK

caltaj@seznam.cz 